\title{
The Effect of Three Types of Written Feedback on Student Motivation
}

\author{
Peter M. Duppenthaler \\ Tezukayama Gakuin University
}

This article reports on the effect of three types of written feedback on student motivation at a girls' private high school in Japan. It addresses the question of whether students who receive meaning-focused feedback show a greater degree of positive motivation than students who receive either positive comments or error-focused feedback. The only statistically significant difference among the three types of feedback was that the positive-comments group was significantly less eager to get their journals back each week than the meaningfocused feedback group. The overall findings of this study reconfirm the positive effect journal writing, regardless of feedback type, has on motivation. All three groups reported that they felt it had a positive effect on their English, and that it had been a worthwhile experience for them.

本論文は、日本の某私立女子高校を調査対象にして、英文日記の 3 通りの筆記 によるフィードバック法を比較し、それらが生徒のややる気 $>$ に及ぼす効果につ いて報告したものである。日記の「内容に関するフィードバック」を受ける生徒 が、「誉め言葉によるフィードバック」、あるいは英語の「誤謬訂正のフィード バック」を受けるものよりも、よりくやる気 >を引き起こされるものかどうかと いう点を検証した。3通りのフィードバックを比較して、統計数值上唯一有意差 があったのは、「誉め言葉のフィードバック」を受けるグループは、「内容に関 するフィードバック」を受けるグループに比べて、毎週の日記の返却（つまりフ イードバックされること）にそれほど熱心ではなかったということである。ただ 研究全般から再確認できることは、いかなるフィードバックであれ、英文日記を 書くことは、英語学習に対する生徒のくやる気 >に対してプラス効果を及ぼすと いうことであり、それは 3 グループすべての生徒が、日記をつけることは自分た ちの英語にプラス効果をもたらし、やりがいのあるものであったと報告している ことに表れている。

JALT Journal, Vol. 24, No. 2, November, 2002 
7 he larger one-year study on which this article is based (see Duppenthaler, 2002) investigated the effect of three different 1 types of feedback on the "improvement" of students' journal entries, the possibility of a transfer effect to in-class compositions, and possible influence on the strength of motivation. The present article is limited to the question of motivation (see Stern, 1983; Oxford, 1994; and Dörnyei, 2001 for overviews and general discussions of motivation). The research question was: Do students who receive meaning-focused feedback show a greater degree of positive motivation than students who receive either positive comments or error-focused feedback?

The three types of feedback provided in the students' journals were (a) meaning-focused feedback, in which I engaged in an ongoing and cumulative, interactive dialog with the participants, providing commentary on the content of each journal entry, suggesting future topics, and asking for additional information and clarification; (b) positive comments, in which I responded with phrases such as "well done," "keep up the good work" and "keep writing," and with occasional short positive comments on the content of a few scattered journal entries so that students would know, as in the case of the other two treatment groups, that I was reading their entries, but did not engage in an ongoing interactive dialog, or ask for additional information and clarification; and (c) error-focused feedback, in which I corrected all errors, in red ink, in the participants' journal entries with no revision required on the part of the participants.

A review of the literature indicated that several researchers (Leki, 1992; Holmes \& Moulton, 1997) had voiced the opinion that meaning-focused feedback had a positive effect on motivation. Although some researchers (Semke, 1984; Robb, Ross, \& Shortreed, 1986; Aly, 1992, Fazio, 2001) reported little positive value for error correction, many students seem to prefer it (see for example Cathcart \& Olsen, 1976; Radecki \& Swales, 1988; Harrison, 1993; Timson, Grow, \& Matsuoka, 1999). It was therefore felt that error-focused feedback might be viewed positively by students, and thus might lead to increased motivation. Finally, it was felt that positive comments should be included as one of the treatment types because informal discussions with teachers in Japanese high schools who had used journals led me to believe that this was a common, if not the most common, type of feedback.

Although, in a general sense, meaning-focused feedback may seem to fit into the general feedback category of commentary, in which the teacher makes written comments or asks questions focused on either 
grammatical errors, content, or the students' ideas, it is in fact a rather different thing in that it is not intended to be evaluative. "Commentary" in this case consists of exchanges in which the teacher is "a participant in an ongoing written conversation with the student, rather than an evaluator who corrects or comments on the students' writing" (Worthington, 1997, p. 3).

With regard to error correction, Radecki and Swales (1988), Cathcart and Olsen (1976), and Harrison (1993), all reported that students prefer teachers to correct all surface errors at least to the extent that it is possible. A survey by Timson, Grow, and Matsuoka (1999) to determine the error correction preferences of 1,228 Japanese, second language learners enrolled in various departments at nine universities in Japan found overwhelming agreement among their respondents that "error correction is necessary and desirable in order to increase second language fluency" (p. 145) and that "a majority of those surveyed desire to have their errors corrected" (p. 145).

There may be several possible explanations for the popularity of error correction among students. The main one may simply be that many teachers use this type of feedback. This may mean that students are used to it and therefore comfortable with it. It may also be seen as the type of feedback that requires the least effort on the students' part. After all, all students need to do to improve the original draft is to rewrite, copying the corrections that the teacher has already made for them, reducing their main task to one of reading the teacher's handwriting.

According to Staton (1988), the publication of two National Institute of Education reports, "Analysis of Dialogue Journal Writing as a Communicative Event," and "Dialogue Writing: Analysis of Student-Teachers Interactive Writing in the Learning of English as a Second Language," "stirred increased interest in the use of dialogue journals in the ESL community" (p. xi). However, even before this, the classroom use of journals was not all that uncommon. The Journal Book (1987), edited by Toby Fulwiler, a longtime proponent of using journals, contains 42 articles, by 42 different authors, all singing the praises of journal writing in teaching situations from elementary school through university, and in disciplines as varied as English poetry and experimental physics. The entire volume "is about journals, and their use in developing students' minds and selves" (Staton, 1987, p. 4). The authors in this collection frequently mention the positive effects on motivation that journals have.

An additional impetus for the use of journals as ESL/EFL language teaching tools was given by TESOL's (Teachers of English to Speakers of Other 
Languages) publication of two books specifically dealing with journal writing, Students and Teachers Writing Together: Perspectives on Journal Writing (Peyton, 1990) and Dialogue Journal Writing with Nonnative English Speakers: A Handbook for Teachers (Peyton \& Reed, 1990).

Over the years, journals have not only been used in language teaching classrooms throughout the world but have also been used in work with deaf children (Staton, 1985; Kluwin \& Blumenthal, 1991), as a part of preservice teacher training programs (Brinton \& Holten, 1988; Bacon, 1995), in multilingual classes (McFarland, 1992; Moulton \& Holmes, 1994), with the learning-disabled (McGettigan, 1987; Gaustad \& Messenheimer-Young, 1991), with gifted children (Armstrong 1994), through the media of computers and e-mail (McQuail, 1995; Yeoman, 1995), and as a means of enhancing communication and understanding in schools (Dana, 1993; Hanrahan, 1999). As Kirby, Liner, and Vinz (1988) note, "the journal is one of those phenomena of English teaching: an instant hit with teachers everywhere. It zoomed like a skyrocket through every cookbook and conference ... it has been used and abused at one time or another by most English teachers" (p. 57).

The popularity of journals can also be seen as a natural extension of the Whole Language movement as outlined by Goodman (1986), which "rests upon the premise that language is more easily acquired when teaching and learning are all inclusive, contextualized and purposeful" (de Godev, 1994, p. 2), and by the work of Swain $(1985,1995)$ and others on input and output (see Woodfield, 1997; and Robinson, 1997 for more on input and output). In addition, Holmes and Moulton (1997) note the fairly commonly held view that "through responding to the content of students' writing and not correcting errors, teachers can...[control] affective variables that affect the writer's motivation" (p. 620) and report that their students believed that journal writing enhanced their motivation to write and increased their fluency.

There have been a number of studies carried out in Japan involving the use of journals (see for example Konoeda, 1997; Hirose \& Sasaki, 2000). The nine articles in the collection of articles edited by Casanave (1993a) on the use of journals at the Shonan Fujisawa campus of Keio University and Keio High School are of particular relevance to this study. Not only do they deal with journal writing in Japan, but also several describe teacher-student dialogue journals. However, only one of the articles (Harrison, 1993) deals with the use of journals in a high school setting.

All of the authors in the collection are positively disposed toward the 
use of journals even though, as many of them point out, they require a great deal of time and energy on the part of the teachers. Casanave is fairly representative when she writes, "In the Japan context, at least, journal writing may constitute the single most beneficial activity for the development of students' confidence and communicative ability in English" (p. 4).

Casanave (1993b) used written and oral data in both English and Japanese to investigate students' views on journal writing. The subjects consisted of four intact classes with 30 students in each class. The students engaged in journal writing during the course of one semester. At the end of the semester the students were asked to write a journal entry on their journal writing experience. They were not asked to respond to detailed questions, but simply to comment in any way they wished on what the experience of journal writing had been like for them. Casanave then used these final entries, along with interviews, as her data source. She found that the majority, but not all, of the students found the journal experience to be a positive one. "They believe that their English language and writing abilities improved, that they became more fluent writers (and in some cases, speakers), and that they developed personally and intellectually through the journal writing process" (p. 4).

Although researchers who have investigated the students' own opinions on what they think of the experience of journal writing, usually through interviews and questionnaires, generally report positive feelings toward the experience, there are always at least a few students who report that they do not like keeping journals (see for example Lucas, 1990, 1992; Casanave, 1993b; Holmes \& Moulton, 1995; Skerritt, 1995).

It is interesting to note that both Holmes and Moulton (1995) and Casanave (1993b) mentioned that students who had more experience with the target language were the least comfortable with (i.e., the most negative about) journal writing. In the case of Holmes and Moulton, one student, Dang, the "reluctant participant" in the title of their article, had spent five years in the United States during which time he had graduated from an American high school. Holmes and Moulton note that if teachers bothered to ask, "they would probably find that there is a contrarian like Dang in every class" (p. 242).

Casanave (1993b) also reported that, "A handful of other students, particularly returnee students [i.e., returning to live in Japan after having lived abroad for a period of time] at the end of three semesters of English, remarked that they 'hated journal writing,' yet recognized that it benefited their English in a number of ways" (p. 100). It is interesting to 
note that Radecki and Swales (1988), in their study of ESL students' reactions to written comments on their essays also found, through student questionnaires, that as students progress in their English language development they become less tolerant of their teachers' feedback and "more restricted [in] the role they generally assign to the English instructor" (p. 364). However, they go on to say that they had "little hard evidence of any relationship between the type of student respondent and the proficiency level in ESL writing" (p. 364). Skerritt (1995) found that students felt the experience worthwhile only if it allowed for personal reflection and if they were certain that the teacher was reading their entries.

The present study built on the existing body of research on journals in educational settings. It extended it in four ways: (a) by using journals as a means of delivering different types of feedback, (b) by carrying it out in a new environment (i.e., a Japanese girls' high school), (c) by using a relatively large sample size of 99 students, and (d) by providing treatment over an entire academic year.

\section{Methods}

\section{Site}

The school at which this study was carried out is a girls' high school of mid-sized enrollment in the Kansai area. The general emphasis of the English program at the school is almost equally divided between the four skills of reading, writing, speaking, and listening, but with a slightly heavier emphasis on reading and writing. English is a required subject at the school from junior high school through high school. It is a fairly typical Japanese high school in that the teachers consider their main job to be the preparation of students for college entrance exams. Even though, due to the decline in the birth rate, there are now more places at colleges and universities than applicants, there is still competition to enter topranking institutions of higher learning; any high school whose students can enter such schools will have fewer problems in attracting potential students and thus a greater chance of survival. This opinion seems to be fairly common among Japanese high school teachers whether they are working at public or private high schools.

\section{Participants}

Second-year students at the school are divided into five levels based on their performance during their first year of high school: one higher-level class, one middle-level class, and three lower-level classes. 
The students in the three lower-level classes are assigned to individual classes on the basis of alphabetical order. The 99 participants in this study consisted of the students in the three lower-level classes. Secondyear students were selected for a number of reasons. First, the teachers felt that second-year students had enough English and time to write a journal in English. In fact, they felt that this was the only year that it was possible for the students to do it--first-year students were either too busy getting used to school or did not have enough English to be able to write a journal in English, and third-year students were either too busy preparing for entrance exams or under too much pressure worrying about taking them. Second, the lower-level students were selected because they constituted the largest group of students at one ability level. Third, the teachers were less willing to involve higher-level students in anything that might "distract" them from their main task of preparing for college entrance exams. Finally, it was assumed that motivation would be less of a problem for higher-level student and that any increase in motivation might have a greater positive effect on lower-level students.

\section{Materials}

\section{Bilingual Pretreatment Questionnaire}

A bilingual pretreatment questionnaire was developed by the author in consultation with the Japanese English teachers at the school and an American consultant with several years of teaching experience at a Japanese high school in Japan. The final version (see first 10 questions in Appendix 1) consisted of ten questions designed to determine the students' language history (i.e., familiarity with and exposure to English outside of their regular classes). It was used to check for any pretreatment differences among the three groups.

\section{Bilingual Posttreatment Questionnaire}

A bilingual posttreatment questionnaire (see Appendix 1) was also developed by the author in consultation with the group mentioned above. The final version consisted of 20 questions. The first ten questions were exactly the same as those in the pretreatment questionnaire and were used to check for any differences among treatment groups that might have occurred during the year. Questions 11 through 20 were designed to find out how the students had felt about keeping a journal, and to see if the experience had resulted in any motivational differences among the three groups. 
The posttreatment questionnaire was given at the end of the academic year. No significant differences were found among the three treatment groups with regard to their degree of extracurricular exposure to English prior to the study (i.e., the first ten questions). An examination of the raw data showing how many students selected each option indicated that the numbers had remained almost exactly the same as in the case of the pretreatment questionnaire. In other words, there had been no changes with regard to extracurricular English activities during the course of the year.

Questions 11 through 20, which did not appear in the Pretreatment Questionnaire, were designed to determine (a) the degree of either positive or negative feelings the students had toward writing in their journals and (b) whether they felt the experience had been a positive one irrespective of how they had felt about having to do the writing or about putting in the time and effort. A 5-point Likert scale was used for each question $(1=$ strongly agree, $2=$ agree, $3=$ neither agree nor disagree, $4=$ disagree, 5 = strongly disagree). Question 20 was designed to elicit a written response in English. All of the students wrote comments. I coded these using the same 5-point Likert scale used for the other questions so that the question could be included in the statistical analysis with the other questions. In this case, students who wrote that they liked English more than before were given a four or a five depending on the strength of their response. Students who wrote that their attitude had not changed were given a three. Those who wrote that it had had a negative influence were given a one or a two depending on the strength of their response.

\section{Procedures}

In order to avoid the problem of group differences-always a possibility with intact classes-the students were blocked into three treatment (i.e., feedback) groups, according to their scores on a 40-item, multiple-choice cloze test, during the first week of school (Group 1, meaning-focused; Group 2, positive comments; Group 3, error-focused). The split-half adjusted reliability for the cloze test was .82. As mentioned before, all second-year students are divided into five classes based on their performance during their first year of high school. The students in the three lower-level classes (i.e., those who took part in this study) are then assigned to their three respective classes on the basis of alphabetical order. These students are therefore a rather homogeneous group of individuals. Reliability can be depressed by a number of 
different factors: a small number of items in the test, setting, time span, history, and the homogeneity of the group being tested. As noted by Ary, Jacobs, and Razavieh, (1990), "The reliability coefficient increases as the spread, or heterogeneity, of the subjects who take the test increases. Conversely, the more homogeneous the group is with respect to the trait being measured, the lower will be the reliability coefficient" (p. 280). Given the extreme likelihood of this being a rather homogeneous group, it was felt that the level of reliability was acceptable for blocking purposes. Students were blocked into three groups consisting of exactly 33 students per group (for more on block design see Kirk, 1995).

The result of this procedure was that each treatment group was made up of a similar proportion of students who were enrolled in classes which were taught by each of the teachers who taught the second-year students (i.e., students were blocked both by ability and across class lines). I was therefore, able to control for course content, possible initial ability level differences among the students, and teacher and instructional differences that might have occurred during the students' regular course of study. In addition, several other procedures were carried out in order to ensure that there were no significant differences among the groups prior to treatment.

During the second week of school, the participants filled in the bilingual pretreatment questionnaire. An analysis of the questionnaire indicated that there were no significant differences among the three treatment groups. Because questions 1, 4, 5, and 9 were Yes/No questions they were coded using "one" for yes and "zero" for no. The dichotomous nature of these questions meant that logistic regression, rather than ANOVA or Linear Regression, was the preferred method of analysis. This was because unlike ANOVA and Regression, in which the dependent variable should be continuous, "Logistic [Regression] is relatively free of restrictions, and with the capacity to analyze a mix of all types of predictors (continuous, discrete, and dichotomous)" (Tabachnick \& Fidell, 1996, p. 578). In this type of analysis, if the chi-square is small, "then one concludes that the two variables are independent; a poor fit leads to a large chi-square ... and the conclusion that the two variables are related" (Tabachnick \& Fidell, 1996, p. 56). Logistic regression for questions 1, 4, 5, and 9 in the Pretreatment Questionnaire showed small chi-square and $p$ values, which indicated that there were no significant differences among the three groups.

Pretreatment Questionnaire questions 2, 3, 6, 7, 8, and 10 were on a scale, which meant that a multivariate analysis of variance (MANOVA), 
rather than ANOVA, was the preferred method of analysis because the research design included more than one dependent variable. Like ANOVA, MANOVA is a statistical procedure for testing whether the difference among the means of two or more groups is significant. However,

MANOVA has a number of advantages over ANOVA. First, by measuring several DVs [Dependent Variables] instead of only one, the researcher improves the chance of discovering what it is that changes as a result of different treatments and their interactions... A second advantage of MANOVA over a series of ANOVAs when there are several DVs is protection against inflated Type I error [i.e., rejection of a true null hypothesis] due to multiple tests of (likely) correlated DVs. (Tabachnick \& Fidell, 1996, pp. 375-376)

A one-way MANOVA for Pretreatment Questionnaire questions 2, 3, $6,7,8$, and 10 also showed no significant differences among the three treatment groups.

The students also completed an in-class writing assignment during the second week of school. The in-class writing sheet included a simple set of instructions in English, a four-frame picture sequence that the students were to use as the basis for a 200 to 250 word story, the first line of the story, and space to write the story and record the number of words written. The picture sequence was selected for its clear story line and because it did not require prior knowledge of the subject. A number of researchers (Ross, Shortreed, \& Robb, 1988; Rousseau, Bottge, \& Dy, 1993; Ishikawa, 1995) have used similar picture sequences to gather writing samples from students.

A one-way MANOVA was performed on the in-class writing assignment using total number of words, number of error-free clauses, number of clauses, four vocabulary indices generated by the VocabProfile computer program (sometimes called the LFP [Lexical Frequency Profile]), and the Flesch-Kincaid Readability Index as the dependent variables, and group assignment as the independent variable. No significant differences were found.

The results of the above analyses served to indicate that there were no significant group differences among the three treatment groups. In addition, in order to determine if any significant differences had existed among the three treatment groups at the beginning of the treatment, a one-way MANOVA was performed using the first four weeks of journal entries. There were no significant differences among the three treatment groups. 
The results of the above analyses all indicated that there were no significant differences among the three treatment groups at the outset of the study. The possible novelty of the treatment (i.e., Hawthorne effect) would seem to have been eliminated by the fact that the treatment lasted for one year.

The above would all seem to indicate that any significant differences among the three groups that might have developed during the course of the academic year could be attributed to the effect of the treatment the students received during that time rather than to any group differences that might have existed prior to the outset of the treatment period, or to group differences which might have been the result of differences in ability, course content, teacher or instructional methods.

During the course of the year, the students wrote in their journals on a weekly basis. The journals were collected at the end of each week. I read each journal, provided the appropriate feedback, and returned them to the school so that the students could collect their journals from their homeroom teachers on the following Monday.

\section{Analysis}

Procedures related to the identification of possible outliers, the evaluation of the assumptions of normality of sampling distributions, homogeneity or variance-covariance matrices, linearity, and multicollinearity were carried out following recommendations found in Tabachnick and Fidell (1996). The overall alpha level of this study was set at .05; however, a Bonferroni type adjustment was made in order to guard against inflated Type I error. The adjusted alpha for all Multivariate Analysis of Variance tests was set at .005 (the original alpha level of .05 divided by 10, the total number of Mulitvarate Analysis of Variance tests in the study). In addition an adjustment was made in the alpha level for all Univariate $\mathrm{F}$ tests. In this case, the adjusted alpha for the Mulitvarate Analysis of Variance tests (.005) was divided by the number of dependent variables (DVs). In the case of the pretreatment and posttreatment questionnaires the adjusted alpha was .0005 (.005/10 DVs).

The descriptive statistics for the Posttreatment Questionnaire items directly related to motivation (questions 11 through 20) are presented in Table 1. It should be noted here that in this particular case the three treatment groups were slightly unequal in size, (Group 1, 30 students; Group 2, 30 students; and Group 3, 29 students). This was because three or four students in each group had not answered all of the questions and the statistical program being used automatically drops such cases from 
the analysis. However, this slight difference in group size should have no effect on the overall findings.

Table 1: Descriptive Statistics for Posttreatment Questionnaire Questions 11 through 20

Question(Q) Min Max Mean Std.Err. Std.Dev. Skewness Kurtosis

\begin{tabular}{llllllll}
\hline Q11 & 1.0 & 5.0 & 2.489 & 0.1042 & 0.999 & 0.502 & -0.170 \\
Q12 & 1.0 & 4.0 & 1.934 & 0.0824 & 0.786 & 0.538 & -0.096 \\
Q13 & 1.0 & 5.0 & 2.733 & 0.1169 & 1.109 & 0.196 & -0.363 \\
Q14 & 1.0 & 5.0 & 2.196 & 0.0992 & 0.952 & 0.610 & 0.245 \\
Q15 & 1.0 & 5.0 & 2.560 & 0.1107 & 1.056 & 0.271 & -0.357 \\
Q16 & 1.0 & 5.0 & 2.619 & 0.0975 & 0.935 & 0.342 & 0.020 \\
Q17 & 1.0 & 4.0 & 1.826 & 0.0882 & 0.846 & 0.675 & -0.416 \\
Q18 & 1.0 & 5.0 & 2.891 & 0.1053 & 1.010 & 0.418 & -0.172 \\
Q19 & 1.0 & 5.0 & 2.326 & 0.1348 & 1.293 & 0.643 & -0.642 \\
Q20 & 1.0 & 5.0 & 2.511 & 0.0920 & 0.883 & 0.259 & -0.227 \\
\hline
\end{tabular}

A one-way MANOVA analysis of questions 11 through 20 indicated significant differences among the three groups at $p=.0006$ (see Table 2 ). These questions were on a scale, which meant that a multivariate analysis of variance (MANOVA), rather than ANOVA, was the preferred method of analysis because the research design included more than one dependent variable.

Table 2: Multivariate Analysis of Variance $($ Effect $=$ Group) Posttreatment Questionnaire Questions 11 through 20

\begin{tabular}{lccccc}
\hline Effect & Wilks' Lambda & Rao's R & df 1 & df 2 & p-level \\
\hline 1 & 0.5637 & 2.555 & 20 & 154 & $.0006611^{*}$ \\
\hline
\end{tabular}

$* p<.005$ 
As we can see in Table 2, instead of the univariate $F$ value, the multivariate $F$ value, Wilks' lambda, and Rao's $R$ are shown. The MANOVA module of the statistical software program used in this study uses three different multivariate test criteria (Wilks' lambda, Rao's $R$, and PhillaiBartlett trace) and reports two of these in the Table of all Effects as shown in Table 2. These tests are "based on a comparison of the error variance/covariance matrix and the effect variance/covariance matrix. The 'covariance' here is included because the measures [i.e., variables] are correlated and you must take this correlation into account when performing the significance test" (StatSoft, 1984, p. 387).

Univariate $F$ tests for each dependent variable, with the adjusted alpha of $p<.0005$ used in order to guard against inflated Type I error, indicated that there was one significant difference: Question 19 (I looked forward to getting my journal back each week) at $p=.0000$ (see Table 3).

Table 3: Univariate F Tests with Degrees of Freedom $(2,86)$ Table of Specific Effects for Posttreatment Questionnaire Questions 11 through 20

\begin{tabular}{lcccc}
\hline Question (Q) & $\begin{array}{c}\text { Mean Sqr } \\
\text { Effect }\end{array}$ & $\begin{array}{c}\text { Mean Sqr } \\
\text { Error }\end{array}$ & $\begin{array}{c}\mathrm{f}(\mathrm{df1}, 2) \\
2,86\end{array}$ & p-level \\
\hline Q11 & 2.277 & 0.900 & 2.528 & 0.0857 \\
Q12 & 0.221 & 0.591 & 0.374 & 0.6886 \\
Q13 & 6.906 & 1.112 & 6.205 & 0.0030 \\
Q14 & 0.241 & 0.928 & 0.259 & 0.7718 \\
Q15 & 1.887 & 1.117 & 1.688 & 0.1908 \\
Q16 & 0.761 & 0.871 & 0.873 & 0.4211 \\
Q17 & 0.758 & 0.621 & 1.221 & 0.2999 \\
Q18 & 0.926 & 0.982 & 0.942 & 0.3935 \\
Q19 & 13.266 & 1.290 & 10.278 & $0.0000 *$ \\
Q20 & 0.302 & 0.786 & 0.385 & 0.6815 \\
\hline
\end{tabular}

$* p<.000$

As mentioned earlier, the use of the MANOVA allows us to determine if there are significant differences among group means when there are several dependent variables. The use of a post hoc test allows us to determine exactly where these significant differences lie. As the three groups were slightly unequal in size, post hoc comparisons were conducted 
using both the Tukey HSD (Honest Significant Difference) for unequal sample sizes and the Scheffé test. Although these two tests produced the same results, the Scheffé test proved to be the more conservative and was therefore used (see Table 4).

Table 4: Scheffé Test for Posttreatment Questionnaire Question 19

\begin{tabular}{lcccc}
\hline & & $\{1\}$ & $\{2\}$ & $\{3\}$ \\
GROUP & (means) & 1.833333 & 3.033333 & 1.931034 \\
\hline 1 & $\{1\}$ & & 0.0004780 & 0.9469634 \\
2 & $\{2\}$ & $0.0004780^{*}$ & & 0.0016049 \\
3 & $\{3\}$ & 0.9469634 & 0.0016049 & \\
\hline$* p<.0005$ & & &
\end{tabular}

As can be seen from the above (Table 4), with regard to question 19, Group 2 was significantly different from Group 1, but there were no other significant differences.

In order to interpret the results of the posttreatment questionnaire let us look at Table 5. Table 5 shows a list of questions, 11 through 20, with each question number and the average for each group. For the questionnaire, $1=$ strongly agree, 2 = agree, $3=$ neither agree nor disagree, $4=$ disagree, and $5=$ strongly disagree. The wording of each question is included in Table 5 for the reader's convenience.

Table 5: Posttreatment Questionnaire

Questions 11 through 20 Averages

\begin{tabular}{lcccccccccc}
\hline Question & Q11 & Q12 & Q13 & Q14 & Q15 & Q16 & Q17 & Q18 & Q19 & Q20 \\
\hline $\begin{array}{l}\text { Group 1 } \\
\text { Average }\end{array}$ & 2.3 & 1.9 & 2.2 & 2.2 & 2.8 & 2.6 & 1.8 & 2.9 & 2.0 & 2.5 \\
$\begin{array}{l}\text { Group 2 } \\
\text { Average }\end{array}$ & 2.6 & 2.0 & 2.9 & 2.3 & 2.3 & 2.6 & 2.0 & 2.8 & 3.0 & 2.6 \\
$\begin{array}{l}\text { Group 3 } \\
\text { Average }\end{array}$ & 2.8 & 2.0 & 3.2 & 2.4 & 2.8 & 3.0 & 1.9 & 3.3 & 2.2 & 2.7 \\
\hline
\end{tabular}


Table 5 (Continued)

Question 11: I enjoyed writing in my journal.

Question 12: I think writing in my journal had a positive effect on my English.

Question 13: I would like to continue writing in a journal next year.

Question 14: I enjoy writing in English more now than I did a year ago.

Question 15: I think my writing is better now than a year ago.

Question 16: I can express myself in writing more easily now than a year ago.

Question 17: I think writing in my journal was a good experience for me.

Question 18: Writing in my journal made me want to study English more.

Question 19: I looked forward to getting my journal back each week.

Question 20: Has writing a journal changed your attitude toward English?

\section{Results and Discussion}

The reliability of self-report questionnaires is always suspect and this fact should be kept in mind when interpreting the results of this study as well as any other that uses them. However, it should also be kept in mind that "almost all motivation assessment uses some sort of 'self report' measure" (Dörnyei, 2001, p. 199).

In order to interpret the results of the posttreatment questionnaire, the following standard was used: $1.8-2.3=$ agree, $2.4-2.8=$ agree less strongly, $2.9-3.3=$ neutral, 3.4-5 disagree. Using this standard we can interpret the above averages for each question as follows:

Question 11: Group 1 most enjoyed writing in the journals, with the other two groups enjoying the journals, but to a lesser degree.

Question 12: All groups agreed that writing in their journals had a positive effect on their English.

Question 13: Group 1 agreed it would like to continue writing in a journal next year, while Groups 2 and 3 neither agreed nor disagreed. 
Question 14: Groups 1 and 2 enjoyed writing in English more at the end of the year than a year earlier. This sentiment was shared to a slightly lesser degree by Group 3.

Question 15: Group 2 felt that its writing was better than a year earlier, and the other two groups agreed to a lesser extent that their own writing had improved.

Question 16: Group 3 neither agreed nor disagreed that it could express itself in writing more easily than a year earlier, but Groups 1 and 2 agreed slightly that they could do so.

Question 17: All groups felt that writing in a journal was a good experience.

Question 18: Group 2 felt to some extent that writing in a journal made them want to study English more, but Groups 1 and 3 were neutral about this.

Question 19: Groups 1 and 3 looked forward to getting their journals back each week, but Group 2 was neutral on this.

Question 20: All groups agreed to some extent that writing journals had changed their attitude toward English. An examination of the written comments accompanying this question indicated that almost all of the comments were positive.

As can be seen from the above, all three groups tended to be more positive than negative toward the journal experience. With regard to the question in which there was a significant group difference (Question 19), Group 2 was significantly less eager than Group 1 to get the journals back each week, and both Groups 1 and 3 looked forward to getting the journals back each week (mean: Group $1=1.8$, Group $2=$ 3.0, Group 3 = 1.9).

Questions 11 through 20 on the Posttreatment Questionnaire were designed to determine (a) the degree of either positive or negative feelings the students had with regard to writing in their journals, and (b) whether they felt the experience had been a positive one. The results of a MANOVA indicated a significant difference among the three groups at $p=.0006$. Univariate $F$ tests indicated one significant difference in Question 19 ("I looked forward to getting my journal back each week.") at $p=$ .0000. Post hoc analyses showed that with regard to Question 19, Group 2 was significantly different from Group 1 at $p=.0004$. Group 1 had the lowest average, which showed that Group 1 had the most positive re- 
sponse to Question 19, followed closely by Group 3, while Group 2 was more negative on this point than either Groups 1 or 3 (average: Group $1=2$, Group $2=3$, Group $3=2.2$ ). Although these significant differences are of interest, perhaps more important for classroom teachers seeking ways to motivate their students is that it would appear, from Table 5, that all three groups "claimed" to be positively disposed to journal writing. In addition, all three groups reported that they felt it had a positive effect on their English, and that it had been a "good experience" for them.

\section{Further Study}

Much work remains to be carried out in the field of motivation. It is "one of the most elusive concepts in the whole domain of the social sciences" (Dörnyei, 2001, p. 2). And yet few if any would deny the profound effect it has on learning. Journals, at least for the students involved in this study, seemed to have a positive effect on motivation. However, it is an undeniable fact that responding to journals takes time. This is one of the main drawbacks to journals mentioned in the literature. The question of time is one that definitely needs to be addressed. What is the relationship between motivation and frequency of journal entries? Is there an optimal frequency and if so, then what is it? In addition, is there some point at which frequency of journal entries crosses over to what Dörnyei (2001, p. 141) has called "the 'dark side' of motivation" (i.e., demotivation)?

A replication of this study at a Japanese boys' high school and at a Japanese coeducational high school, as well as similar institutions in different cultural settings would provide valuable data for comparing the effects of various types of feedback in different settings. Such studies would also lend themselves to an examination of possible gender and cultural differences. It is quite possible that journals are more effective with one gender or cultural group than another.

There is also a need to find out if there is a relationship between the students' levels of English or, possibly, time spent abroad in English-speaking environments, and their feelings towards journal writing. Perhaps as students become more proficient they may also become both more aware of and more concerned about their own errors and shortcomings, and therefore find the experience more intimidating (see for example Radecki \& Swales, 1988; \& Casanave, 1993b). Perhaps such students feel ready to move on to more structured (i.e., academic) types of writing. They may perceive this as more demanding, challenging and prestigious than journal writing. With the increasing number of returnees in Japan this would undoubtedly be a very interesting area of research. 


\section{Conclusion}

The overall findings of this study reconfirm the positive effect journal writing has on motivation, regardless of feedback type. Journals, as many have noted (Reed, 1988; Jones, 1988; Baskin, 1994) provide opportunities to connect with students in a personal, non-threatening way, opening up their world to teachers in ways that would not otherwise be possible.

During the last few years the Japanese Ministry of Education (Monbu-kagaku-sho) has reduced the number of hours that students study English in class in junior and senior high school. Although writing and responding to journals takes time, this does not need to be class time. Journals therefore represent a valuable addition to class time, and provide students with a way to practice language production in a communicative context.

According to Ellis (1994), "Language teachers readily acknowledge the importance of learners' motivation ... [and] SLA research also views motivation as a key factor in L2 learning" (p. 508). The overall findings of this study support the positive effect of journal writing on motivation, regardless of feedback type, and the slightly greater overall positive effect of meaning-focused feedback. All of the groups were positively motivated by the journal experience. If it is true that "What teachers usually wish to know is how they can intervene, that is, what they can actually do to motivate learners" (Dörnyei, 2001, p. 116), then the positive effects on motivation reported by the students in this study are well worth considering. "To be motivated to learn, students need both ample opportunities to learn and steady encouragement and support of their learning efforts" (Good \& Brophy, 1994, p. 215). The use of journals provides just such opportunities.

\section{Acknowledgments}

I would like to thank the editor and the two anonymous reviewers of JALT Journal for their insightful comments on the earlier draft of this paper.

Peter Duppenthaler is a professor in the Faculty of Literature at Tezukayama Gakuin University. His research interests include journals, motivation, and strategy use. 


\section{References}

Aly, M. S. (1992). A descriptive study of four EFL teachers' treatment of writing errors and their feedback in an Arab country. Unpublished doctoral dissertation, Indiana University of Pennsylvania, PA.

Armstrong, D. C. (1994). A gifted child's education requires real dialogue: The use of interactive writing for collaborative education. Gifted Child Quarterly, 38(3), 136-145.

Ary, D., Jacobs, L. C., \& Razavieh, A. (1990). Introduction to research in education (4th ed.). Fort Worth, TX: Harcourt Brace College Publishers.

Bacon, S. M. (1995). Coming to grips with the culture: Another use of dialogue journals in teacher education. Foreign Language Annals, 28(2), 193-207.

Baskin, R. S. (1994). Student feedback on dialogue journals. National Institute of Education, Educational Resources Information Center. (ERIC Document Reproduction Service No. ED 375 627)

Brinton, D., \& Holten, C. (1988, March). Dialog journals: A window on the act of language teaching. Paper presented at the Annual Meeting of the Teachers of English to Speakers of Other Languages, Chicago, IL.

Casanave, C. P. (Ed.). (1993a). Journal Writing: Pedagogical Perspectives. Institute of Languages and Communication, Keio University, SFC (Shonan Fujisawa Campus).

Casanave, C. P. (1993b). Student voices: The insiders speak out on journal writing. In C. P. Casavave (Ed.), Journal Writing: Pedagogical Perspectives (pp. 95-115). Institute of Languages and Communication, Keio University, SFC (Shonan Fujisawa Campus).

Cathcart, R. L. \& Olsen, J. E. W. B. (1976). Teachers' and students' preferences for correction of classroom conversation errors. In J. F. Fanselow \& R. H. Crymes (Eds.), On TESOL '76: Selections based on teaching done at the 10th annual TESOL convention, New York, March 2-7, 1976 (pp. 41-53). Washington, DC: TESOL.

Dana, N. F.(1993, April). Teachers for change: An elementary school collaborative program for enhancing school climate. Paper presented at the Annual Meeting of the American Educational Research Association, Atlanta, GA.

de Godev, C. B. (1994). A rationale to integrate dialog journal writing in the foreign language conversation class. U. S. Department of Education, National Institute of Education, Educational Resources Information Center. (ERIC Document Reproduction Service No. ED 375 679)

Dörnyei, Z. (2001). Teaching and researching motivation. Edinburgh Gate, UK: Pearson Education Limited.

Duppenthaler, P. (2002). Feedback and Japanese high school English language journal writing. Unpublished doctoral dissertation, Temple University, Philadelphia, PA.

Ellis, R. (1994). The study of second language acquisition. Oxford: Oxford University Press.

Fazio, L. L. (2001). The effect of corrections and commentaries on the journal 
writing accuracy of minority- and majority-language students. Journal of Second Language Writing, 10, 235-249.

Fulwiler, T. (Ed.). (1987). The journal book. Portsmouth, NH: Heinemann.

Gaustad, M. G., \& Messenheimer-Young, T. (1991). Dialogue journals for students with learning disabilities. Teaching Exceptional Children, 3(3), 28-32.

Good, T. L., \& Brophy, J. E., (1994). Looking in classrooms (6th ed.). New York: HarperCollins.

Goodman, K. (1986). What's whole in whole language? Portsmouth, NH: Heinemann.

Hanrahan, M. (1999). Rethinking science literacy: Enhancing communication and participation in school science through affirmational dialogue journal writing. Journal of Research in Science Teaching, 36(6), 699-717.

Harrison, M. R. (1993). The role of teacher response in high school journal writing. In C. P. Casanave (Ed.), Journal Writing: Pedagogical Perspectives (pp. 71-77). Institute of Languages and Communication, Keio University, SFC (Shonan Fujisawa Campus).

Hirose, K., \& Sasaki, M. (2000). Effects of teaching metaknowledge and journal writing on Japanese university students' EFL writing. JALT Journal, 22(1), 94-113.

Holmes, V. L., \& Moulton, M. R. (1995). A contrarian view of dialogue journals: The case of a reluctant participant. Journal of Second Language Writing, 4(3), 223-251.

Holmes, V. L., \& Moulton, M. R. (1997). Dialogue journals as an ESL learning strategy. Journal of Adolescent and Adult Literacy, 40(8), 616-621.

Ishikawa, S. (1995). Objective measurement of low-proficiency EFL narrative writing. Journal of Second Language Writing, 4(1), 51-69.

Jones, P. M. (1988). Knowing opportunities: Some possible benefits and limitations of dialogue journals in adult second language instruction. Unpublished doctoral dissertation, School for International Training, Brattleboro, VT.

Kirby, D., Liner, T., \& Vinz, R. (1988). Inside out: Developmental strategies for teaching writing (2nd ed.). Portsmouth, NH: Heinemann.

Kirk, R. E. (1995). Experimental design: Procedures for the behavioral sciences (3rd ed.). Pacific Grove, CA: Brooks/Cole Publishing Company.

Kluwin, T. N., \& Blumenthal, K. A. (1991). The effectiveness of dialogue journal writing in improving the writing skills of young deaf writers. American Annals of the Deaf, 136(3), 284-291.

Konoeda, Y. (1997). Why do some students write more than others in journal writing? Journal of Humanities, 21, 14-27.

Leki, I. (1992). Understanding ESL writers: A guide for teachers. Portsmouth, NH: Heinemann.

Lucas, T. (1990). Personal journal writing as a classroom genre. In J. K. Peyton (Ed.), Students and teachers writing together: Perspectives on journal writing (pp. 65-97). Washington, DC: TESOL.

Lucas, T. (1992). Diversity among individuals: Eight students making sense 
of classroom journal writing. In D. E. Murray (Ed.), Diversity as resource: Redefining cultural literacy (pp. 202-232). Washington, DC: TESOL.

McFarland, K. (1992, February). Case studies of the dialogue journal in multicultural education. Paper presented at the Annual Conference of the National Association for Multicultural Education, Orlando, FL.

McGettigan, K. (1987). Dialogue journal: An initiation into writing. Journal of Reading, Writing, and Learning Disabilities International, 3(4), 321-332.

McQuail, J. A. (1995). Electronic exchanges: Five ways to use electronic networking in the literature classroom. Paper presented at the Annual Meeting of the Conference of College Composition and Communication, Washington, DC.

Moulton, M. \& Holmes, V. L. (1994). Writing in a multicultural classroom: Using dialogue journals to ease transitions. College ESL, 4(2), 12-25.

Oxford, R. L. (1994). Variables, individual, in language learning: Classroom implications. In R. E. Asher (Ed.), The Encyclopedia of Language and Linguistics Vol. 9, (pp. 4893-4899). Princeton NJ: Pergamon Press.

Peyton, J. K. (1990). Dialogue journal writing and the acquisition of English grammatical morphology. In J. K. Peyton (Ed.), Students and teachers writing together: Perspectives on journal writing (pp. 65-97). Washington, DC: TESOL.

Peyton, J. K., \& Reed, L. (1990). Dialogue journal writing with nonnative English speakers: A handbook for teachers. Alexandria, VA: TESOL.

Radecki, P., \& Swales, J. (1988). ESL student reaction to written comments on their written work. System, 16(3), 355-365.

Reed, L. (1988). Dialogue journals make my whole year flow: The teacher's perspective. In J. Staton, R. W. Shuy, J. K. Peyton, \& L. Reed (Eds.), Dialogue journal communication: Classroom, linguistic, social, and cognitive views (pp. 56-72). Norwood, NJ: Ablex.

Robb, T., Ross, S., \& Shortreed, I. (1986). Salience of feedback on error and its effect on EFL writing quality. TESOL Quarterly, 20(1), 83-93.

Robinson, P. (1997). State of the art: SLA research and second language teaching. The Language Teacher, 21(7), 7-16.

Ross, S., Shortreed, I., \& Robb, T. (1988). First language composition pedagogy in the second language classroom: A reassessment. RELC Journal, 19(1), 2948.

Rousseau, M. K., Bottge, B. A., \& Dy, E. B. (1993). Syntactic complexity in the writing of students with and without mental retardation. American Journal of Mental Retardation, 98(1), 113-120.

Semke, H. (1984). Effects of the red pen. Foreign Language Annals, 17(3), 195202.

Skerritt, M. E. (1995). Early secondary students' views on the writing journal's ability to be a self motivator of writing. (Report) (ERIC Document Reproduction Service No. ED 385848 )

Staton, J. (1985). Using dialogue journals for developing thinking, reading, and 
writing with hearing-impaired students. The Volta Review, 87(5), 127-154.

Staton, J. (1987). The power of responding in dialogue journals. In T. Fulwiler (Ed.), The Journal Book (pp. 47-63). Portsmouth, NH: Heinemann.

Staton, J. (1988). An introduction to dialogue journal communication. In J. Staton, R. W. Shuy, J. K. Peyton, \& L. Reed (Eds.), Dialogue journal communication: Classroom, linguistic, social, and cognitive views (pp. 1-32). Norwood, NJ: Ablex.

StatSoft. (1984). STATISTICA for the Macintosh. Tulsa, OK: StatSoft, Inc.

Stern, H. H. (1983). Fundamental concepts of language teaching. Oxford: Oxford University Press.

Swain, M. (1985). Communicative competence: Some roles of comprehensible input and comprehensible output in its development. In S. Gass \& C. Madden (Eds.) Input and Second Language Acquisition (pp. 235-253). Rowley, MA: Newbury House.

Swain, M. (1995). Three functions of output in second language learning. In G. Cook \& B. Seidlhofer (Eds.), Principles and practices in applied linguistics: Studies in honour of H. G. Widdowson (pp. 125-144). Cambridge: Cambridge University Press.

Tabachnick, B. G., \& Fidell, L. S. (1996). Using multivariate statistics (3rd ed.). New York: Harper Collins College Publishers.

Timson, S., Grow, A., \& Matsuoka, M. (1999). Error correction preferences of second language learners: A Japanese perspective. JACET Bulletin, 30, 135148.

VocabProfile. (n. d.). User's manual. Wellington, New Zealand: Victoria University, English Language Institute.

Woodfield, D., J. (1997). Output and beyond to dialogue: A review of Merrill Swain's current approach to SLA. The Language Teacher, 21(9), 19-20.

Worthington, L. (1997). Let's not show the teachers: EFL students' secret exchange journals. Forum, 35(3), 2-10.

Yeoman, E. (1995). "Sam's cafe": A case study of computer conferencing as a medium for collective journal writing. Canadian Journal of Educational Communication, 24(3), 209-229.

(received March 12, 2002; revised June 24, 2002)

\section{Appendix 1}




\section{Bilingual Pretreatment Questionnaire}

Class (

) $\mathrm{No}($

) Name

\section{Part 1: LANGUAGE HISTORY 言語歴}

1. Have you ever been to an English-speaking country? 英語圏の国へ行ったことがありますか?
No (go to \#5)
Yes (go to \#2)

2. How long were you there? そこに滞在した期間は?
a. less than a week
（1週間以内）
b. 1 to 2 weeks
（1-2週間）
c. 2 weeks to 3 months
（2週間以上3ヶ月以内）
d. 3 months to 1 year
（3ケ月以上 1 年未満）
e. more than 1 year
（1年以上）

3. How old were you at that time? 何歳くらいの時でしたか?
a. 0-5 years old
c. 11-14 years old
b. 6-10 years old
d. 15-18 years old

4. Did you study English while you were there?

その国では英語を習いましたか?

Yes No

5. Do you study English outside of school? 学校以外でも英語を習っていますか?

$$
\text { No (go to \#8) Yes (go to \#6) }
$$

6. Where do you study? どこで（誰に）習っていますか?
a. Eikaiwa school 英会話学校
b. private tutor, native English speaker 個人教授（ネイティブの先生）
c. private tutor, non-native English speaker 個人教授（ノン・ネイティブの先生）
d. other その他

7. How long have you studied in the place you circled in \#6?

（上記6でこれまでどのくらいの期間習つてきましたか?） 

a. less than a week
（1週間以内）
b. 1 to 2 weeks
（1-2週間以内）
c. 2 weeks to 3 months
(2週間以上3ヶ月以内)
d. 3 months to 1 year
（3ケ月以上 1 年未満）
e. more than 1 year
(1年以上)

8. Do you ever speak English with your family or friends? (家族の人や友人と英語で話すことがありますか? )
a. Yes, several times a week
(一週間に数回)
b. Yes, several times a month
(一ケ月に数回)
c. Yes, rarely
（まれに）
d. No, never
(英語ではなすことはない)

9. Do you have pen pals in foreign countries?

(外国に文通友達がいますか? )

$$
\text { Yes (go to \#10) No }
$$

10. How often do you write to them?

(その友達に手紙を書くのは...)
a. at least once a week
（少なくとも一週間に1回）
b. at least once a month
（少なくとも一ケ月に1回）
c. several times a year
(一年に数回)
d. once a year
（一年に1回）

Part 2: WRITING 英語を書くことに関して

$$
\begin{aligned}
& 1=\text { strongly agree （全くその通りだと思う） } \\
& 2 \text { = agree （まあまあその通りだと思う） } \\
& 3=\text { neither agree nor disagree （どちらでもない） } \\
& 4=\text { disagree （どちらかというとそう思わない） } \\
& 5 \text { strongly disagree （全くそうは思わない） }
\end{aligned}
$$

11. ( ) I enjoyed writing in my journal. 楽しんでジャーナルが書けた 
12. ( ) I think writing in my journal had a positive effect on my English.

ジャーナルを書いたことは自分の英語にプラスであった

13. ( ) I would like to continue writing in a journal next year. 来年度もジャーナル書きを続けたいと思う

14. ( ) I enjoy writing in English more now than I did a year ago. 一年前に比べて英語を楽しんで書けるようになった

15. ( ) I think my writing is better now than a year ago. 一年前に比べて自分の英語は進歩したと思う

16. ( ) I can express myself in writing more easily now than a year ago.

一年前に比べて自分の言いたいことがより簡単に表せる ようになった

17. ( ) I think writing in my journal was a good experience for me. ジャーナルを書いてきたことは自分にとつていい経験 だったと思う

18. ( ) Writing in my journal has made me want to study English more.

ジャーナルをかくことによって英語の学習意欲がより強まった

19. ( ) I looked forward to getting my journal back each week. 毎週ジャーナルが返ってくるのが楽しみであった

20. ( ) Has writing a journal changed your attitude toward English? ジャーナルを書くことによって英語に対する取り組み や考え方が変わりましたか 